ROCZNIKI TEOLOGICZNE

Tom LXVIII, zeszyt 9 - 2021

DOI: https://doi.org/10.18290/rt.21689.4

KS. MAREK SKIERKOWSKI

\title{
JEZUS W AMERYKAŃSKIM JUDAIZMIE REFORMOWANYM XIX WIEKU
}

\author{
JESUS IN THE NINETEENTH-CENTURY AMERICAN REFORM JUDAISM
}

A b s t r a c t. The article deals with the beginning of American Reform Judaism in relation to Jesus. The open and friendly environment gave the Jews a new kind of historical experience, first of all freedom of their research. They created a more positive perception of Christianity by showing that Jesus did and taught nothing contrary to Jewish belief. But at the same time this Jewish reclamation of Jesus proved itself incompatible with Christian claims about Him. In this way Christian Apology called traditionally "Contra/Adversus Judaeos" gained a new constructive beginning to be continued more powerfully later. This article is a (critical) presentation of the writings of Isaac Mayer Wise, Kaufmann Kohler and Emil Gustav Hirsch. They present Jesus in terms of an enthusiastic patriot, an Essenic culmination and a mild Pharisee.

Keywords: Reform Judaism; Jesus; credibility; apology; USA.

WSTĘP

Na przestrzeni XIX stulecia diaspora żydowska w USA wzrosła z około 2-2,5 tysiąca do (w przybliżeniu) jednego miliona wyznawców. W $1824 \mathrm{r}$. w Charleston (Południowa Karolina) grupa 47 członków żydowskiej kongregacji Beth Elohim zażądała od swoich władz decyzyjnych m.in. nabożeństw

Ks. prof. dr hab. MAREK SKIERKOWSKI - Katedra Teologii Fundamentalnej i Prakseologii Apologijnej w Instytucie Teologii Uniwersytetu Kardynała Stefana Wyszyńskiego w Warszawie, ul. Dewajtis 5, 01-815 Warszawa; e-mail: marek.skierkowski1@wp.pl; ORCID: https://orcid.org/ 0000-0002-3513-7264. 
w języku angielskim. Wskutek odrzucenia tej petycji niektórzy intelektualiści założyli odrębną kongregację, przystosowaną już bardziej do zmieniającego się kontekstu historyczno-cywilizacyjnego (która istniała od 21 listopada 1824 r. do 1833 r.); był to niejako początek amerykańskiego judaizmu progresywnego (progressive American Judaism). Niebawem powstał pierwszy reformowany modlitewnik amerykański The Sabbath Service and Miscellaneous Prayers Adopted by the Reformed Society of Israelites ${ }^{1}$. W $1900 \mathrm{r}$. można było znaleźć w USA już 99 kongregacji judaizmu reformowanego, obejmujących łącznie 9800 członków ${ }^{2}$. Okazuje się, że demokratycznie nastawione środowisko chrześcijan amerykańskich różnych denominacji zainspirowało Żydów także do bardziej przychylnego traktowania Jezusa. W poprzednich wiekach ogólnoświatowy judaizm propagował na ogół talmudyczny wizerunek Jezusa, jednakże haskala (żydowskie oświecenie) dała podstawy do naukowej weryfikacji takiego stanowiska. W Europie trwał wówczas proces tzw. pierwszego poszukiwania Jezusa historycznego, w którym przypatrywano się Jezusowi niezależnie od wiary Kościoła. Ten trop okazał się niezwykle kuszący dla judaizmu reformowanego.

W niniejszym artykule chodzi właśnie o tożsamość Jezusa w amerykańskim judaizmie reformowanym XIX stulecia, czyli w fazie początkowej tego nurtu poza Europą. Wówczas refleksję nad tożsamością Jezusa i Jego relacją do judaizmu podjęli tacy znaczący Żydzi amerykańscy, jak: Isaac Mayer Wise, Kaufmann Kohler i Emil Gustav Hirsch ${ }^{3}$. Celem opracowania jest uchwycenie, metodologicznej i treściowej, specyfiki tego nowego poczatku w relacjach między chrześcijaństwem i judaizmem.

\section{ENTUZJASTYCZNY PATRIOTA (I.M. WISE)}

Isaac Mayer Wise (1819-1900) to architekt amerykańskiego judaizmu reformowanego, urodzony na Morawach (Steingrub; wtedy Cesarstwo Austrii). Pierwsze wykształcenie otrzymał od swojego ojca, szkolnego nauczyciela ${ }^{4}$,

\footnotetext{
${ }^{1}$ Por. Dana E. Kaplan, „Reform Judaism”, w Encyclopaedia Judaica, red. Fred Skolnik, Michael Berenbaum, vol. 17 (Detroit i in.: Thomson Gale, 2007), 166-167.

2 Por. tamże, 170.

${ }^{3}$ Inni, pominięci, to np.: Bernhard Felsenthal, Joseph Krauskopf, Joseph Leonard Levy, Harris Weinstock, Max Schlesinger, Louis Weiss, Moses Aaron Dropsie and Emanuel Schreiber.

${ }^{4}$ Por. Max B. May, Isaac Mayer Wise. The Founder of American Judaism. A Biography (New York and London: The Knickerbocker Press, 1916), 24-25.
} 
potem uczył się i studiował w Pradze i Wiedniu; w 1842 r. został rabinem. Jako przewodniczący Hebrew Union College ordynował aż 61 rabinów (chodzi tu o lata 1883-1899) ${ }^{5}$. W 1843 r. przejął obowiązki rabina w Radnitz k. Pilzna (dziś Radnice w Czechach) ${ }^{6}$, ale już w 1846 r. wyemigrował do Nowego Jorku ${ }^{7}$ (był rabinem kolejno w kongregacjach Beth El i Anshe Emet w Albany - lata 1846-1854), a potem (od 1854 r.) osiadł na stałe w Cincinnati (Ohio), gdzie zamieszkiwało około 5 tys. Żydów. Posługiwał tutaj jako rabin w kongregacji Bene Yeshurun ${ }^{8}$ (liczącej od 180 do 400 członków $^{9}$ ), ale także wydawał po angielsku czasopismo „The Israelite” (od 1954 r.; potem zmiana tytułu na „The American Israelite”), z niemieckim dodatkiem „Die Deborah”10. W 1875 r. założył i przewodził Hebrew Union College ${ }^{11}$, a od 1889 r. kierował instytucją Central Conference of American Rabbis ${ }^{12}$. Był dwukrotnie żonaty (najpierw, w 1844 r., poślubił Theresę Bloch, a potem, w 1876 r., Selmę Bondi; miał także dzieci) ${ }^{13}$. Uważał, że wiek XIX jest czasem „bardziej dociekania niż refleksji”"14, a w swoich Reminiscences przyznawał, iż krytykował chrześcijaństwo „z racjonalistycznego stanowiska”, początkowo nawet wątpił w historyczną egzystencję Jezusa ${ }^{16}$. Był przekonany, że „bez Talmudu perfekcyjne zrozumienie źródłowego chrześcijaństwa jest prawie niemożliwe" 17 .

W książce The Origin of Christianity and a Commentary to the Acts of the Apostles zajął się najbardziej podstawowym dziełem odsłaniającym genezę chrześcijaństwa, czyli Dziejami Apostolskimi; w nich ścierają się bowiem

${ }^{5}$ Por. tamże, 31.

${ }^{6}$ Por. tamże, 32.

7 Por. tamże, 42.

${ }^{8}$ Por. tamże, 153-193.

${ }^{9}$ Por. tamże, 192.

${ }^{10}$ Por. tamże, 194-256.

${ }^{11}$ Por. tamże, 257-321.

12 Por. tamże, 322-354.

${ }^{13}$ Por. tamże, 379-381.

${ }^{14}$ Isaac M. Wise, Three Lectures on the Origin of Christianity (Cincinnati: Bloch \& CO., Publishers, 1883), 3.

${ }^{15}$ Reminiscences by Isaac M. Wise, tłum. z niemieckiego i red. David Philipson (Cincinnati: Leo Wise and Company, 1901), 122.

${ }^{16}$ Por. Walter Jacob, Christianity Through Jewish Eyes. The Quest for Common Ground (Cincinnati: Hebrew Union College Press, 1974), 82.

${ }^{17}$ Por. Isaac M. Wise, The Origin of Christianity and a Commentary to the Acts of the Apostles (Cincinnati: Bloch \& CO., Publishers, 1868), VI. 
dwa pierwotne systemy tej religii, czyli system Piotra, Jakuba i Jana oraz system Pawła i jego kontynuatorów ${ }^{18}$. Credo pierwszego systemu chrześcijańskiego opierało się na przekonaniu, że oczekiwany Mesjasz już przyszedł, ale został ukrzyżowany; przyjdzie On jednak powtórnie, by ustanowić królestwo Dawidowe ${ }^{19}$. A konkretniej: „Piotr obwieszcza mesjanizm Jezusa, kosztujący Mesjasza utratę życia. Po śmierci Jezusa Piotr proklamuje Jego powtórne przyjście i nadzieję z tym związaną, czyli odnowę tronu Dawidowego, znajdując pewnych, aczkolwiek nielicznych, zwolenników"20. I wtedy pojawia się na scenie historii Paweł, ortodoksyjny faryzeusz, który przez wzgląd na misję wobec pogan przystosowuje „koncepcję rabinicznego Metatrona do postaci Piotrowgo Mesjasza ukrzyżowanego" ${ }^{21}$. Metatron to w literaturze rabinicznej wielki duch pośredniczący, znajdujący się obok Bożego Tronu, utożsamiany na ogół w ówczesnej interpretacji żydowskiej z Henochem; dla Pawła jest nim jednak właśnie Jezus, określany bardziej przystępnie jako „Syn Boży”22. „Dzisiejsze chrześcijaństwo - podsumowuje I. Wise - pozostaje niepodobne do chrześcijaństwa Piotrowego i ma niewiele wspólnego z chrześcijaństwem Pawłowym. [...] Chrystologia Kościoła stanowi bowiem produkt wieków ciemności i nie ma nic wspólnego z naukami Jezusa, jak je propagowali czy to Piotr, czy to Pawel"

W książce The Martyrdom of Jesus of Nazareth I. Wise stwierdza, że żadna $\mathrm{z}$ ewangelii kanonicznych nie została napisana w I wieku ${ }^{24}$; najwcześniejsza z nich, mianowicie Mk, czyli „najmniej legendarna i najbardziej epicka”, powstała między 120 a 138 rokiem $^{25}$. Jej autor, pierwszy nieżydowski biskup Jerozolimy, a wcześniej mistrz szkoły w Aleksandrii, stworzył w ten sposób dzieło, które miało być traktowane jako część Pisma Świętego, gdy cesarz Hadrian po powstaniu Bar Kochby zabronił posługiwania się Biblią Hebrajską ${ }^{26}$. Ci Żydzi („tuzin lub dwa”), którzy uważali, że Jezus powinien zostać zgładzony, nie reprezentowali swojego narodu, lecz jedynie

\footnotetext{
18 Por. tamże, VI.

19 Por. tamże, 179.

${ }^{20}$ Por. tamże, 533-534.

${ }^{21}$ Tamże, 340-341.

22 Por. tamże, 340.

23 Tamże, 535.

${ }^{24}$ Por. Isaac M. Wise, The Martyrdom of Jesus of Nazareth: a Historic-Critical Treatise on the Last Chapters of the Gospel (Cincinnati: Office of the American Israelite, 1874), 12.

25 Tamże, 13.

${ }^{26}$ Por. tamże, 14.
} 
wspierane przez siebie okupacyjne władze rzymskie ${ }^{27}$. Wystapili oni przeciwko Jezusowi w sposób ,ściśle tajny”28 (konspiracyjny), a to z tej racji, że w Jerozolimie (i okolicy) znajdowało się wówczas około dwóch milionów pielgrzymów świętujących Paschę ${ }^{29}$. Jezus, uznawany przez swoich sympatyków za Mesjasza, miał świadomość, że oni przygotowują demonstracyjne ujawnienie Jego mesjanizmu, co może doprowadzić do politycznej interwencji władz rzymskich i okropnej rzezi ogromu ludzi ${ }^{30}$. Podejmuje On zatem wspaniałomyślnie decyzję, by oddać się jak najszybciej w ręce Rzymian, poświęcając $w$ ten sposób swoje życie celem uchronienia (wybawienia) innych od śmierci ${ }^{31}$. Dlatego podczas pożegnalnej wieczerzy z uczniami ponagla Judasza, by poinformował arcykapłanów o zbliżającej się demonstracji mesjańskiej w Jerozolimie ${ }^{32}$. W tej perspektywie narracja o rzekomym stawieniu Jezusa przed nocnym sądem Sanhedrynu pozostaje całkowicie sprzeczna $\mathrm{z}$ prawem i zwyczajami żydowskimi; jest więc fikcją wytworzoną w II wieku w kontekście już wyraźnie nieżydowskim ${ }^{33}$. Piłat po wydaniu wyroku śmierci na Jezusa przekazał Go w ręce żołnierzy, by dokonali na Nim egzekucji bez zbędnej zwłoki i poza oczami ludzi; nie ma jednak pewności, czy oni faktycznie uśmiercili Go poprzez ukrzyżowanie (być może na widok publiczny powieszono tylko martwe ciało rzekomego króla Żydów? ${ }^{34}$.

W książce History of the Hebrews' Second Commonwealth with Special Reference to its Literature, Culture, and the Origin of Rabbinism and Christianity Wise zaprezentował historię epoki Drugiej Świątyni, odnosząc się w XXI rozdziale, zatytułowanym The Messianic Commotion (Mesjański za$m e ̨ t$ ), do Jezusa ${ }^{35}$. Przedstawia Go jako prominentnego ucznia Jana Chrzciciela, głoszącego ludziom naukę o pokucie, ascezie i chrzcie celem przywrócenia królestwa; „w Jezusowym umyśle zakorzeniła się głęboko religijna idea

\footnotetext{
${ }^{27}$ Por. tamże, 16.

${ }^{28}$ Por. tamże, 17.

${ }^{29}$ Por. tamże, 34-35.

${ }^{30}$ Por. tamże, 40.

${ }^{31}$ Por. tamże, 40-41.

32 Por. tamże, 41.

33 Por. tamże, 77.

${ }^{34}$ Por. tamże, 126.

35 Por. Isaac M. Wise, History of the Hebrews' Second Commonwealth with Special Reference to its Literature, Culture, and the Origin of Rabbinism and Christianity (Cincinnati: Bloch \& CO., Publishers and Printers, 1880), 258-267.
} 
patriotyzmu"36. Talmud wskazuje na Jego pochodzenie z Nazaretu (Notzri); niewiele jednak wiadomo o Jego rodzicach i młodości; ewangeliści portretują Go jako syna Dawida, a także syna Bożego - i z tej właśnie racji wskazują na Jego dziewicze narodziny; według Talmudu, jakiś czas uczył się w Egipcie pod okiem konkretnego rabbiego; posiadł m.in. także znajomość magii; do Palestyny wrócił jako lekarz ${ }^{37}$. W Galilei podjął zadanie wędrownego nauczyciela, zyskując zwolenników wśród klas niższych, a ze strony ludzi światłych spotykając się raczej z chłodnym odbiorem; uzdrowienia, których dokonywał, jawiły się dla tych pierwszych jako cudowne, dla tych drugich zaś jako niedorzeczne ${ }^{38}$. Niebawem Jezus wykroczył poza wąską optykę Jana Chrzciciela i nauczał w duchu hillelickim; ignorował charakterystyczne dla szammaitów i kapłanów przepisy o czystości rytualnej; porzucił także ascetyczny styl życia Jana Chrzciciela i począł praktykować radosną wspólnotę stołu z grzesznikami ${ }^{39}$. Przemawiał za pomocą sentencji i przypowieści, traktując Biblię jako swój najwyższy autorytet; wyróżniał się żarliwą sympatią do ludzi, stałymi przekonaniami i moralną odwagą $^{40}$. Określał siebie mianem Syna Człowieczego, spodziewając się, że będzie wiodącym władcą w przywróconym mocą Bożego ducha, a nie zelockim orężem militarnym, królestwie ${ }^{41}$. Po aresztowaniu Jana Chrzciciela stał się niemal notorycznym zbiegiem ${ }^{42}$. Niechętnie przyjął zasugerowane przez Szymona Piotra przekonanie, że jest Mesjaszem (zresztą, obce hillelitom) ${ }^{43}$. Pod eskortą ogromnego entuzjazmu swoich zwolenników znalazł się w Jerozolimie, gdzie napotkał opór ze strony religijnych władz świątynnych; arcykapłan Kajfasz, zaniepokojony wybuchem insurekcji, zdecydował postawić Go przed Piłatem, ale Jezus, świadomy niebezpieczeństwa krwawego stłumienia powstania, podjął decyzję, za pośrednictwem Judasza, by samemu oddać się w ręce okupowanych władz i zginąć patriotyczną śmiercią męczeńską ${ }^{44}$.

W książce Three Lectures on the Origin of Christianity Isaac Wise stwierdził, że Jezus był „faryzejskim uczonym i entuzjastycznym żydowskim patrio-

\footnotetext{
36 Tamże, 258.

${ }^{37}$ Por. tamże, 258-259.

38 Por. tamże, 260.

${ }^{39}$ Por. tamże, 260-261.

${ }^{40}$ Por. tamże, 261.

${ }^{41}$ Por. tamże, 262-263.

${ }^{42}$ Por. tamże, 263-264.

${ }^{43}$ Por. tamże, 264-265.

${ }^{44}$ Por. tamże, 266-267.
} 
tą"45. W całej działalności „nigdy On nie zachęcał do naruszenia jakiegokolwiek przepisu Prawa; nie miał też idei stworzenia nowej religii" ${ }^{46}$; zawsze „pozostawał w doskonałej harmonii z przepisami faryzeizmu” ${ }^{47}$; ,antyfaryzejski duch ewangelii jest produktem II wieku" ${ }^{48}$; wtedy także zaczęto przypisywać Jezusowi cuda ${ }^{49}$. Podobnie w książce Judaism and Christianity. Their Agreements and Disagreements. Wise podkreśla, że Jezus, który proklamował „starożytną demokratyczną teokrację" w Objawieniu Synajskim ${ }^{51}$, a Jego Kazanie na Górze ma paralele w Biblii Hebrajskiej i Talmudzie ${ }^{52}$. Oznacza to, że Kalwaria, symbolizująca chrześcijaństwo, „nie wniosła niczego nowego do etyki Synaju"53.

W książce A Defense of Judaism versus Proselytizing Christianity rabin amerykański wskazuje na ogólną nieskuteczność misji chrześcijan wobec Żydów w ciągu wieków; np. w Cincinnati za jego pobytu zwerbowano zaledwie jedna osobę, gdy tymczasem na judaizm przeszło 37 chrześcijan ${ }^{54}$. Żyd nie może przyjąć dogmatów Kościoła, gdyż zostały one wyprowadzone ze sprzecznych wzajemnie opowiadań o Jezusie, na podstawie których z trudem można wykazać nawet samo Jego istnienie ${ }^{55}$. Chrystologia Kościoła zatem jest dziełem ludzkiej pomysłowości i spekulacji, bez podstawy w pismach Starego Testamentu ${ }^{56}$.

\section{KULMINACJA ESSENIZMU (K. KOHLER)}

Kaufmann Kohler (1843-1926) urodził się w Fürth (Bawaria), w pobożnej i ortodoksyjnej rodzinie żydowskiej, studiował w Monachium (1864-1865),

\footnotetext{
${ }^{45}$ Wise, Three Lectures on the Origin of Christianity, 7.

46 Tamże, 19.

47 Tamże, 20.

48 Tamże, 24.

49 Por. tamże, 27.

${ }^{50}$ Isaac M. Wise, Judaism and Christianity. Their Agreements and Disagreements. A Series of Friday Evening Lectures, Delivered at the Plum Street Temple (Cincinnati: Bloch \& CO., Publishers, 1883), 44.

${ }^{51}$ Por. tamże, 44-45.

52 Por. tamże, 45.

53 Tamże, 46.

${ }^{54}$ Por. Isaac M. Wise, A Defense of Judaism versus Proselytizing Christianity (Cincinnati and Chicago: American Israelite, 1889), 10.

55 Por. tamże, 22.

${ }^{56}$ Por. tamże, 61.
} 
Berlinie i Erlangen (doktorat z filozofii w 1867 r.; jego dysertacja Der Segen Jacobs - Błogostawieństwo Jakuba, dotycząca historycznego rozwoju poglądów religijnych w Biblii, tak wykraczała poza judaizm ortodoksyjny czy nawet neoortodoksyjny, którego wcześniej uczył się m.in. od S.R. Hirscha, że nie mógł nigdzie zdobyć zatrudnienia jako rabin, chociaż dyplom na taki urząd uzyskał w 1868 r.); potem jeszcze pobierał nauki orientalne w Lipsku (lata 1868-1869); wreszcie w 1869 r. wyemigrował do USA, gdzie został rabinem w Detroit, a potem w Chicago (od 1871 r.; tutaj w 1874 r. wprowadził nabożeństwa niedzielne) i Nowym Jorku (od 1879 do 1903 r.; urząd przejął po zmarłym teściu Davidzie Einchornie); w 1903 r. został przewodniczącym Hebrew Union College w Cincinnati; cały czas aktywnie angażując się w kreowanie judaizmu reformowanego, pisząc m.in. Jewish Theology Systematically and Historically Considered (1918); po przejściu na emeryturę (1921) wrócił do Nowego Jorku; miał czworo dzieci ${ }^{57}$.

Zdaniem Kohlera, chrześcijaństwo jest córką judaizmu, który pozostaje nieprzewyższalny ${ }^{58}$, mieniąc się jako religia i narodowa, i światowa jednocześnie $^{59}$. Ewangelie pozostają tak obrośnięte mitem i pełne sprzeczności, że dotarcie za ich pośrednictwem do historii Jezusa staje się nad wyraz trudne, aczkolwiek trzeba Go uznać za ,jednego z najlepszych i najprawdziwszych synów Synagogi" ${ }^{60}$, „doskonałego Żyda"61. Wprawdzie uczony amerykański nie umieszcza Jezusa formalnie w gronie esseńczyków ${ }^{62}$ (Jezus

\footnotetext{
57 Por. Sefton D. Temkin i Michael Berenbaum, „Kohler, Kaufmann (1843-1926)”, w Encyclopaedia Judaica, vol. 12, 261; Biographisches Handbuch der Rabbiner, red. Michael Brocke, Julius Carlebach, Teil 1: Die Rabbiner der Emanzipationszeit in den deutschen, böhmischen und großpolnischen Ländern 1781-1871, red. Carsten Wilke (München: K.G. Saur, 2004), nr 0931, 532-535; Max J. Kohler, „Biographical Sketch of Dr. K. Kohler”, w Studies in Jewish Literature Issued In Honor of Professor Kaufmann Kohler, Ph.D. On the Occasion of His Seventieth Birthday (Berlin: Georg Reimer, Publisher and Printer, 1913), 1-10. W tym opracowaniu zbiorowym zamieszczona jest także bibliografia tekstów K. Kohlera sporządzona przez Adolpha S. Oko za lata 1867-1913 (łącznie 801 pozycji), 266-301.

58 Por. Kaufmann Kohler, Jewish Theology Systematically and Historically Considered (New York: The Macmillan Company, 1918), 17.

${ }^{59}$ Por. tamże, 14.

${ }^{60}$ „An Anthology of Jewish Views of Jesus”, w George L. Berlin, Defending the Faith. Nineteenth-Century American Jewish Writings on Christianity and Jesus (New York: State University of New York Press, 1989), 166-167.

${ }^{61}$ Kaufmann Kohler, The Origins of the Synagogue and the Church (New York: Arno Press, 1973; reprint wydania z 1929 r.), 218.

${ }^{62}$ Por. Kaufmann Kohler, „The Essenes and the Apocalyptic Literature”, w tenże, Studies, Addresses, and Personal Papers (New York: The Bloch Publishing Co., Agent, 1931), 20-36.
} 
„,nie przynależał do żadnej szkoły”63), to jednak uważa, że właśnie w Nim essenizm „osiagnął swoją kulminację"64, tutaj bowiem „ideał miłości i wspólnoty przybrał nową i wznioślejszą formę" ${ }^{\circ 5}$.

Wiązanie początku aury mesjańskiej otaczającej Jezusa $\mathrm{z}$ wystapieniem Jana Chrzciciela ma, zdaniem K. Kohlera, charakter późniejszej interpretacji chrześcijańskiej, zbudowanej na egzegezie proroctw Izajasza i Malachiasza $^{66}$. Jego liberalizm w stosunku do szabatu wynikał z ulegania wpływom faryzejskich hillelitów ${ }^{67}$. Do momentu przeprowadzenia akcji w świątyni nie implikował On roszczeń mesjańskich ${ }^{68}$. Przestawanie Jezusa $z$ marginesem społecznym odróżniało Go od innych przywódców religijnych tamtego czasu, ale nie oznaczało jeszcze zerwania z judaizmem ${ }^{69}$. Dopiero Paweł, Żyd hellenistyczny, niemający niczego wspólnego z judaizmem rabinicznym, stworzy chrześcijaństwo, czerpiąc m.in. z gnozy, aczkolwiek ostatecznie jego uniwersalizm nie powiódł się. Podstawą Pawłowej chrystologii będzie rezurekcyjna wizja Jezusa jako nadnaturalnego bytu ${ }^{70}$; ta wizja miała charakter ekstazy na podłożu epileptycznym ${ }^{71}$. Zdaniem K. Kohlera, w procesie narodzin Kościoła istotna jest jednak także popaschalna wizja Piotra, na bazie której uznano mesjanizm Jezusa ${ }^{72}$.

K. Kohler zestawia Jezusa z Mojżeszem ${ }^{73}$. Wielkość Mojżesza wynika z tego, że jego dusza przejęła bezpośrednio na Synaju ogień Boży, stając się iskrą w ciemności świata; ten ogień rozbłysnął potem w każdym Żydzie ${ }^{74}$. Jezus natomiast stanowi emanację essenizmu, tej wspólnoty świętych pustelni-

\footnotetext{
${ }^{63}$ Kaufmann Kohler, ,Synagoge and Church in Their Mutual Relations, Particularly in Reference to Their Ethical Teaching", w tenże, Studies, Addresses, and Personal Papers, 256.

${ }^{64}$ Kaufmann Kohler, „Jesus of Nazareth - In Theology”, w Jewish Encyclopedia, red. Isidore Singer, vol. 7 (New York 1901-1906), 169, http://jewishencyclopedia.com; tenże, Christianity in its Relation to Judaism, w Jewish Encyclopedia, vol. 4, 52; por. The Origins of the Synagogue and the Church, 238.

${ }^{65}$ Kohler, „Synagoge and Church in Their Mutual Relations”, 256.

${ }^{66}$ Por. Kohler, The Origins of the Synagogue and the Church, 208.

${ }^{67}$ Por. Kohler, ,Jesus of Nazareth - In Theology”, vol. 7, 168.

${ }^{68}$ Por. tamże, vol. 7, 169.

${ }^{69}$ Por. Kohler, The Origins of the Synagogue and the Church, 27.

70 Por. tamże, 261.

${ }^{71}$ Por. tamże, 262.

72 Por. tamże, 232-237.

73 Tekst „Moses and Jesus” z Menorah 12 (1892), 158-168, przedrukowany jest w Berlin, Defending the Faith, 120-128.

${ }^{74}$ Por. tamże, 121-122.
} 
ków, którzy praktykowali chrzest i wzywali Ducha ${ }^{75}$. Jezus korzystał także z innych źródeł, nic więc dziwnego, że jedna połowa Jego wypowiedzi pozostaje w sprzeczności z drugą połową ${ }^{76}$. Osobiście lokował się On wyraźnie w bliskości Mojżesza, twierdząc, że nie przyszedł, aby znieść Prawo, lecz je wypełnić; i dlatego nie sposób zrozumieć słów Jezusa z Nowego Testamentu bez znajomości literatury rabinicznej ${ }^{77}$. Wielkość Jezusa polegała ostatecznie na tym, że nadał pokorze nowy majestat, niszcząc bariery między wykształconymi i prostymi ${ }^{78}$. Jego natomiast słabością był sentymentalny idealizm, taka naiwna miłość, której brakowało sprawiedliwości i prawdy ${ }^{79}$; a przecież trzy fundamentalne zasady etyki żydowskiej to prawda, sprawiedliwość i świętość ${ }^{80}$.

\section{UMIARKOWANY FARYZEUSZ (E.G. HIRSCH)}

Emil Gustav Hirsch (1851-1923) urodził się w Luksemburgu jako syn rabina Samuela Hirscha; kiedy ojciec otrzymał urząd rabina judaizmu reformowanego w Filadelfii (1866), zabrał syna do USA, gdzie studiował on m.in. na Uniwersytecie Pensylwanii (w Filadelfii). Niebawem wrócił jednak do Europy, by uczyć się w Berlinie i Lipsku (1872-1876). Potem, pojawiając się znowu w USA, został rabinem w Baltimore (1877-1878), Louisville (18781880) i przede wszystkim w Chicago Sinai Congregation (1880-1923); wykładał również literaturę rabiniczną i filozofię na Uniwersytecie w Chicago (od 1892 r.). Uważano go za wybitnego kaznodzieję, dużo także publikował w piśmie „Reform Advocate”, którego przez wiele lat był redaktorem. Wydał sporo tekstów o Jezusie, aczkolwiek na ogół w formie dłuższych mów ${ }^{81}$.

Chcąc zaprezentować spojrzenie E.G. Hirscha na Jezusa, należy wyjść od publikacji (owocu wygłoszonego wykładu) The Crucifixion Viewed from a Je-

\footnotetext{
75 Por. tamże, 124.

76 Por. tamże, 126.

${ }^{77}$ Por. Kaufmann Kohler, „The Attitude of Christian Scholars Toward Jewish Literature”, w Berlin, Defending the Faith, 159.

${ }^{78}$ Por. Kohler, „Moses and Jesus”, w Berlin, Defending the Faith, 126.

${ }^{79}$ Por. tamże, 126-127.

${ }^{80}$ Por. Kaufmann Kohler, „Three Discourses on Jewish Ethics”, w tenże, Studies, Addresses, and Personal Papers, 242.

${ }^{81}$ Por. Cyrus Adler i Frank H. Vizetelly, „Hirsch, Emil Gustav”, w Jewish Encyclopedia, vol. 6, 410-11; Samuel E. Karff, „Hirsch, Emil Gustave”, w Encyclopaedia Judaica, vol. 9, 124-125.
} 
wish Standpoint (1892). Zdaniem rabina, cztery ewangelie przybrały aktualny kształt dopiero w II wieku, a swoją formą literacką przypominają żydowską hagadę ${ }^{82}$. $Z$ tych dokumentów można wywnioskować, że nauczanie Jezusa pozostaje nieoryginalne; czerpał On całkowicie $\mathrm{z}$ synagogalnych tradycji swojego czasu ${ }^{83}$. Był On ,faryzeuszem [...] należącym do umiarkowanego skrzydła tego nurtu” ${ }^{\text {}}$. Przesłanie moralne, które proklamował, „nie mogło w żaden sposób wzbudzić podejrzenia, a cóż dopiero opozycji, ze strony Żydów, czy to wykształconych, czy prostych" ${ }^{\text {" }}$. Jedyną grupą, w której zakiełkowało wobec Niego wrogie podejrzenie, była rodzina arcykapłańska, współpracująca z Piłatem ${ }^{86}$. Chodzi o to, że Jezus przez swój zupełnie niespodziewany gniew w świątyni, uderzył w ich interesy finansowe; zadenuncjowali Go zatem namiestnikowi rzymskiemu jako potencjalnego rebelian$\mathrm{ta}^{87}$. Za ukrzyżowanie Jezusa odpowiedzialny jest ostatecznie jedynie Piłat, który był „wcieleniem zarówno rzymskiego okrucieństwa, jak i rzymskiego triumfującego samolubstwa. To nie Żydzi ukrzyżowali Chrystusa" ${ }^{\text {"88. }}$

W opracowaniu The Doctrines of Jesus E.G. Hirsch podejmuje zagadnienie nieoryginalności nauczania Jezusa ${ }^{89}$. Odrzuca tezę, że Jezus jakoby „,sięgnął piedestału, na którym żaden Żyd nigdy nie postawił swojej stopy, a nawet nie mógł postawić"90. Faktycznie był On „lojalnym Żydem”" na znakomicie eksponowała „myśli, idee moralne i aspiracje religijne judaizmu tamtego czasu"92. Jezus jawił się jednak oryginalny w tym sensie, że dawnym koncepcjom nadawał „moc, bezpośredniość i głębię,"93. „Przez Jego słowa judaizm został niejako wniesiony w świat; przez Jego imię judaizm zapukał do bramy narodów" 94 .

\footnotetext{
${ }^{82}$ Por. Emil G. Hirsch, The Crucifixion Viewed from a Jewish Standpoint (Chicago: Bloch Publishing Co., 1892), wyd. 2, 8-11.

${ }^{83}$ Por. tamże, 23.

${ }^{84}$ Tamże, 36.

85 Tamże, 28.

${ }^{86}$ Por. tamże, 61.

${ }^{87}$ Por. tamże, 47.

88 Tamże, 63.

${ }^{89}$ Korzystam z przedruku zawartego w Berlin, Defending the Faith, 129-141.

90 Tamże, 133.

91 Tamże, 137.

92 Tamże, 140.

93 Tamże.

94 Tamże.
} 
W opracowaniu My Religion and the Religion of Jesus wykazuje, że istnieje zasadnicza niezgodność między religią Jezusa (tak jak ją prezentują ewangelie) i obecnym chrześcijaństwem. Jezus był „typowym Żydem swego czasu"95, a Nowy Testament stanowi „echo" humanizmu tradycji żydowskiej $^{96}$. Cieniem na ideale Jezusa było choćby Jego bezżeństwo ${ }^{97}$, upodabniające Go do niektórych esseńczyków ${ }^{98}$. Ogólnie rzecz biorąc, judaizm nie może niczego nowego nauczyć się od Jezusa, ale również w tym nauczaniu nie ma czegoś takiego, co przez szacunek wobec judaizmu trzeba byłoby skorygowac ${ }^{99}$.

Wreszcie w opracowaniu The Jews and Jesus ${ }^{100}$ E.G. Hirsch podkreśla, że Jezus „prawdopodobnie nie przynależał do żadnej partii”101. Autodesygnacja Syn Człowieczy, której używał, była już znana choćby prorokowi Ezechielowi, i wskazuje ona na humanistyczne nastawienie Jezusa ${ }^{102}$, On po prostu „należał do nas" 103 .

\section{ZAKOŃCZENIE}

Zasadniczą nowością w podejściu Żydów amerykańskich XIX wieku do Jezusa, w porównaniu z całymi poprzednimi wiekami napiętych relacji między obiema religiami, jest wyraźne sięgnięcie po ewangelie, a nie tylko po literaturę rabiniczną. Dzieje się to jednak jeszcze z inspiracji tzw. pierwszego, czyli oświeceniowego, poszukiwania Jezusa historycznego, kiedy dostrzegano w ewangeliach raczej źródła teologiczne, a nie relacje historyczne. Przecież to dopiero tzw. drugie poszukiwanie (połowa $\mathrm{XX}$ wieku) wypracuje kryteria autentyczności słów i czynów Jezusa (tzw. atomizacja i depaschalizacja źródeł), a końcowa faza tzw. trzeciego poszukiwania (początek XXI wieku) ukaże ewangelie jako zapamiętane relacje o Jezusie. Nic zatem dziwnego, że Żydzi amerykańscy XIX wieku mówią

${ }^{95}$ Emil G. Hirsch, My Religion. Compilation and Biographical Introduction by G. B. Levi (New York: Macmillan, 1925), 35

96 Por. tamże, 43.

${ }^{97}$ Por. tamże, 44.

98 Por. tamże, 45.

${ }^{99}$ Por. tamże.

${ }^{100}$ Por. Emil G. Hirsch, Twenty Discourses (New York: Bloch Publishing Co., 2008), 1-25.

101 Tamże, 18.

102 Por. tamże, 13-15.

103 Tamże, 22. 
niemal jednym głosem o sprzecznościach w ewangeliach, późnym pochodzeniu tych dzieł i antyjudaistycznym nastawieniu redaktorów. W tej perspektywie starają się niejako metodą poszlakową odkryć prawdziwego Jezusa, który ostatecznie okazuje się nie tylko postacią ze wszech miar dla nich sympatyczną, ale również przychylną judaizmowi.

Według Wise'a, Jezus marzył entuzjastycznie o religii teokratycznej bez pośredników, ale Piotr dostrzegł w Nim Mesjasza, który w Jerozolimie mógłby sprowokować krwawą interwencję władz rzymskich na Jego zwolennikach; Jezus więc w duchu głębokiego patriotyzmu sam oddał się w ręce Rzymian. K. Kohler podziwia w Jezusie żydowską doskonałość i dostrzega w Nim jakby emanację i kulminację essenizmu. Wreszcie E.G. Hirsch ocenia nauczanie Jezusa jako nieoryginalne, zaczerpnięte $\mathrm{z}$ faryzejskiej tradycji synagogalnej; znalazł On jednak ostatecznie sprzeciw w rodzinie arcykapłańskiej współpracującej z Piłatem.

Nietrudno zauważyć, że uczeni żydowscy czerpią nie tyle z wielkiej myśli teologicznej Kościoła katolickiego, bo tę uważają w ogromnym stopniu za konfesyjną, ile raczej inspirują się metodologią ówczesnych racjonalistycznych badań nad Jezusem, które traktują jako jedynie naukowe (np. prace H.S. Reimarusa, D.F. Straussa czy E. Renana; nota bene: katolicy nie uczestniczą w tym tzw. pierwszym poszukiwaniu Jezusa historycznego). Taka optyka pozwala im na dość swobodne odrzucanie z Nowego Testamentu materiałów rzekomo mitycznych i stawianie własnych, oryginalnych hipotez w odniesieniu do historii i tożsamości Jezusa. Z perspektywy Third Quest, czyli aktualnego etapu badań historycznych nad Jezusem, największe zastrzeżenia budzi właśnie to rażące umniejszenie przez uczonych żydowskich pozytywnego wpływu życia i działalności Jezusa na powstanie chrześcijaństwa w łonie judaizmu ${ }^{104}$.

Chociaż spojrzenie Żydów amerykańskich XIX wieku na Jezusa jest już dzisiaj raczej naukowo anachroniczne i w dużym stopniu uproszczone (nie można Go wprost określić ani patriotycznym entuzjastą, ani esseńczykiem, ani faryzeuszem), to jednak stanowi ono niejako nowy poczatek w relacjach między judaizmem i chrześcijaństwem; chodzi o to, że w kontekście, charakterystycznej dla USA wolności obywatelskiej i wolności religijnej, Żydzi sięgnęli po ewangelie, by je w odczytywać i interpretować w duchu naukowym, celem odkrycia prawdziwego wizerunku Jezusa.

\footnotetext{
${ }^{104}$ Nurtowi Third Quest poświęciłem dwie książki: Marek Skierkowski, „A swoi Go nie przyjęli” (J 1,11). Teologicznofundamentalna interpretacja Third Quest (Warszawa: Wydawnictwo UKSW, 2006); tenże, Uczłowieczony Bóg. Chrystologia fundamentalna (Płock: Płocki Instytut Wydawniczy, 2013).
} 


\section{BIBLIOGRAFIA}

Adler, Cyrus i Frank H. Vizetelly. „Hirsch, Emil Gustav”. W Jewish Encyclopedia, red. Isidore Singer. Vol. 6, 410-411. New York 1901-1906. http://jewishencyclopedia.com.

Berlin, George L. Defending the Faith: Nineteenth-Century American Jewish Writings on Christianity and Jesus. New York: State University of New York Press, 1989.

Biographisches Handbuch der Rabbiner, red. Brocke Michael, Julius Carlebach. Teil 1: Die Rabbiner der Emanzipationszeit in den deutschen, böhmischen und großpolnischen Ländern 1781-1871, red. Carsten Wilke. München: K.G. Saur Verlag, 2004.

Hirsch, Emil G. The Crucifixion Viewed from a Jewish Standpoint. Chicago: Bloch Publishing Co., 1892.

Hirsch, Emil G. My Religion. Compilation and Biographical Introduction by G. B. Levi. New York: Macmillan, 1925.

Hirsch, Emil G. Twenty Discourses. New York: Bloch Publishing Co., 2008.

Jacob, Walter. Christianity Through Jewish Eyes: The Quest for Common Ground. Cincinnati: Hebrew Union College Press, 1974.

Kaplan, Dana E. „Reform Judaism”. W Encyclopaedia Judaica, red. Fred Skolnik, Michael Berenbaum. Vol. 17, 165-183. Detroit i in.: Thomson Gale, 2007.

Karff, Samuel E. „Hirsch, Emil Gustave”. W Encyclopaedia Judaica, red. Fred Skolnik, Michael Berenbaum. Vol. 9, 124-125. Detroit i in.: Thomson Gale, 2007.

Kohler, Kaufmann. „Christianity in its Relation to Judaism”. W Jewish Encyclopedia, red. Isidore Singer. Vol. 4, 49-59. New York, 1901-1906. http://jewishencyclopedia.com.

Kohler, Kaufmann, „Jesus of Nazareth - In Theology”. W Jewish Encyclopedia, red. Isidore Singer. Vol. 7, 166-170. New York 1901-1906. http://jewishencyclopedia.com.

Kohler, Kaufmann. Jewish Theology Systematically and Historically Considered. New York: The Macmillan Company, 1918.

Kohler, Kaufmann. Studies, Addresses, and Personal Papers. New York: The Bloch Publishing Co., Agent, 1931.

Kohler, Kaufmann. The Origins of the Synagogue and the Church. New York: Arno Press, 1973

Kohler, Kaufmann. „Moses and Jesus”. W George L. Berlin. Defending the Faith: NineteenthCentury American Jewish Writings on Christianity and Jesus. 120-128. New York: State of New York Press, 1989.

Kohler, Kaufmann. „The Attitude of Christian Scholars Toward Jewish Literature”. W George L. Berlin. Defending the Faith: Nineteenth-Century American Jewish Writings on Christianity and Jesus. 154-163. New York: State of New York Press, 1989.

May, Max B. Isaac Mayer Wise: The Founder of American Judaism: A Biography. New York and London: The Knickerbocker Press, 1916.

Reminiscences by Isaac M. Wise. Tłum. z niemieckiego i red. David Philipson. Cincinnati: Leo Wise and Company, 1901

Skierkowski, Marek. „A swoi Go nie przyjęli” (J 1,11). Teologicznofundamentalna interpretacja Third Quest. Warszawa: Wydawnictwo UKSW, 2006.

Skierkowski, Marek. Uczłowieczony Bóg. Chrystologia fundamentalna. Płock: Płocki Instytut Wydawniczy, 2013.

Studies in Jewish Literature, Issued in Honor of Professor Kaufmann Kohler, Ph.D: On the Occasion of His Seventieth Birthday, oprac. zbiorowe. Berlin: Georg Reimer, Publisher and Printer, 1913. 
Temkin, Sefton D. i Michael Berenbaum. „Kohler, Kaufmann (1843-1926)”. W Encyclopaedia Judaica, red. Fred Skolnik, Michael Berenbaum. Vol. 12, 261. Detroit i in.: Thomson Gale, 2007.

Wise, Isaac M. The Origin of Christianity and a Commentary to the Acts of the Apostles. Cincinnati: Bloch \& CO., Publishers, 1868.

Wise, Isaac M. The Martyrdom of Jesus of Nazareth: a Historic-Critical Treatise on the Last Chapters of the Gospel. Cincinnati: Office of the American Israelite, 1874.

Wise, Isaac M. History of the Hebrews' Second Commonwealth with Special Reference to its Literature, Culture, and the Origin of Rabbinism and Christianity. Cincinnati: Bloch \& CO., Publishers and Printers, 1880.

Wise, Isaac M. Three Lectures on the Origin of Christianity. Cincinnati: Bloch \& CO., Publishers, 1883.

Wise, Isaac M. Judaism and Christianity: Their Agreements and Disagreements. A Series of Friday Evening Lectures, Delivered at the Plum Street Temple. Cincinnati: Bloch \& CO., Publishers, 1883.

Wise, Isaac M. A Defense of Judaism versus Proselytizing Christianity. Cincinnati and Chicago: American Israelite, 1889.

\title{
JEZUS W AMERYKAŃSKIM JUDAIZMIE REFORMOWANYM XIX WIEKU
}

\author{
S t r e s z c z e n i e
}

Artykuł dotyczy początków amerykańskiego judaizmu reformowanego w relacji do Jezusa. Otwarte i życzliwe środowisko USA dało Żydom nowy rodzaj historycznego doświadczenia, przede wszystkim wolność ich badań. Wypracowali oni zatem bardziej pozytywne postrzeganie chrześcijaństwa poprzez ukazanie, że Jezus ani nie działał, ani nie nauczał niczego przeciwnego wierze żydowskiej. Jednocześnie jednak takie żydowskie odzyskanie Jezusa okazało się niekompatybilne $\mathrm{z}$ chrześcijańskimi twierdzeniami o Nim. W ten sposób chrześcijańska apologia zwana tradycyjnie „Contra/Adversus Judaeos” znalazła nowy konstruktywny początek, który będzie kontynuowany z większą mocą później. Artykuł stanowi (krytyczną) prezentację pism trzech najważniejszych uczonych żydowskich z tego okresu, którymi są: Isaac Mayer Wise, Kaufmann Kohler i Emil Gustav Hirsch.

Słowa kluczowe: judaizm reformowany; Jezus; wiarygodność; apologia; USA. 